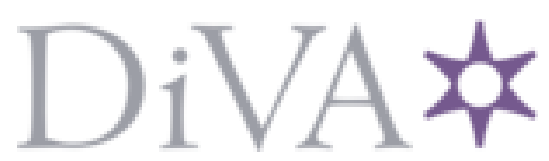

http://www.diva-portal.org

\title{
Postprint
}

This is the accepted version of a paper published in Plant Molecular Biology. This paper has been peerreviewed but does not include the final publisher proof-corrections or journal pagination.

Citation for the original published paper (version of record):

Sooriyaarachchi, S., Jaber, E., Covarrubias, A., Ubhayasekera, W., Asiegbu, F. et al. (2011)

Expression and beta-glucan binding properties of Scots pine (Pinus sylvestris L.) antimicrobial protein (Sp-AMP).

Plant Molecular Biology, 77(1-2): 33-45

http://dx.doi.org/10.1007/s11103-011-9791-z

Access to the published version may require subscription.

N.B. When citing this work, cite the original published paper.

Permanent link to this version:

http://urn.kb.se/resolve?urn=urn:nbn:se:uu:diva- 158571 


\section{Expression and $\beta$-glucan binding properties of Scots pine (Pinus sylvestris L.) antimicrobial protein (Sp-AMP)}

Sanjeewani Sooriyaarachchi ${ }^{1 \&}$, Emad Jaber ${ }^{2 \&}$, Adrian Suárez Covarrubias ${ }^{3}$, Wimal Ubhayasekera $^{1 \S}$, Frederick O. Asiegbu ${ }^{2}$, Sherry L. Mowbray ${ }^{1,3 *}$

${ }^{1}$ Department of Molecular Biology, Swedish University of Agricultural Sciences, Box 590, Biomedical Center, SE-751 24, Uppsala, Sweden

${ }^{2}$ Department of Forest Sciences, University of Helsinki, Box 27, FI-00014 Helsinki, Finland

${ }^{3}$ Department of Cell and Molecular Biology, Uppsala University, Box 596, Biomedical Center, SE-751 24, Uppsala, Sweden

\& Joint first authors.

${ }^{\S}$ Current address: MAX-lab, Lund University, Box 118, S-221 00 Lund, Sweden, and Institute of Medicinal Chemistry, University of Copenhagen, Universitetsparken 2, DK-2100 Copenhagen $\varnothing$, Denmark

* Corresponding author: Tel.: 46-18-471-4990; Fax: 46-18-53-69-71; E-mail: mowbray@xray.bmc.uu.se 


\section{Abbreviations:}

AMP, antimicrobial protein

SA, salicylic acid

MeJA, methyl jasmonate

ACC, 1-aminocyclopropane-1-carboxylic-acid

PDB, Protein Data Bank

PR, pathogenesis-related

qRT-PCR, real-time quantitative reverse transcription PCR

SDS-PAGE, sodium dodecyl sulfate polyacrylamide gel electrophoresis

Sp-AMP, Scots pine antimicrobial peptide/protein (the corresponding gene is italicised) 


\begin{abstract}
Scots pine (Pinus sylvestris) secretes a number of small, highly-related, disulfide-rich proteins (Sp-AMPs) in response to challenges with fungal pathogens such as Heterobasidion annosum, although their biological role has been unknown. Here, we examined the expression patterns of these genes, as well as the structure and function of the encoded proteins. Northern blots and quantitative real time PCR showed increased levels of expression that are sustained during the interactions of host trees with pathogens, but not non-pathogens, consistent with a function in conifer tree defenses. Furthermore, the genes were up-regulated after treatment with salicylic acid and an ethylene precursor, 1-aminocyclopropane-1-carboxylic-acid, but neither methyl jasmonate nor $\mathrm{H}_{2} \mathrm{O}_{2}$ induced expression, indicating that $S p-A M P$ gene expression is independent of the jasmonic acid signaling pathways. The cDNA encoding one of the proteins was cloned and expressed in Pichia pastoris. The purified protein had antifungal activity against $H$. annosum, and caused morphological changes in its hyphae and spores. It was directly shown to bind soluble and insoluble $\beta$-(1,3)-glucans, specifically and with high affinity. Furthermore, addition of exogenous glucan is linked to higher levels of $S p-A M P$ expression in the conifer. Homology modeling and sequence comparisons suggest that a conserved patch on the surface of the globular Sp-AMP is a carbohydrate-binding site that can accommodate approximately four sugar units. We conclude that these proteins belong to a new family of antimicrobial proteins (PR-19) that are likely to act by binding the glucans that are a major component of fungal cell walls.
\end{abstract}

Keywords: antimicrobial protein; Heterobasidion annosum; $\beta$-(1,3)-glucan; chitin; inhibition; binding; homology modeling; pathogen; Pinus sylvestris. 


\section{Introduction}

Plants are attacked by pathogens at all the stages of their life cycle, which is essential for the balance of the ecosystem, but can be economically disastrous when a crop plant is affected. The fungus Heterobasidion annosum is the most destructive pathogen for forest trees in the Northern Hemisphere, causing root and butt rot, especially in conifers such as Scots pine (Pinus sylvestris) (Asiegbu et al. 2005). As a necrotroph, H. annosum is capable of infecting and destroying living conifer roots and stems of all ages, as well as dead trees. Chemicals, biocontrol agents, and silvicultural measures are currently used to control the disease in forest plantations. However, these do not provide full protection, and there is an urgent need for new, more effective and environmentally friendly alternatives.

Antimicrobial proteins or peptides (AMPs) may be considered as a first line of defence in plants (van Loon et al. 2006). All polypeptides showing activity against pathogenic microbes can be designated as AMPs, and those known have very wide functional and structural diversity (Montesinos 2007). Many AMPs have been reported to belong to the so called pathogenesisrelated (PR) proteins (van Loon and Van Strien 1999). As well as pathogenic attacks, other stresses such as drought and wounding often trigger AMP expression (Broekaert et al. 1997). Induction may be mediated through stress-signalling pathways, particularly the jasmonate/ethylene pathways (Thomma et al. 1998).

Recent gene expression analysis revealed a novel family of highly related proteins in Scots pine, designated Sp-AMPs, which are produced constitutively, but up-regulated after challenge with H. annosum (Asiegbu et al. 2003). Sp-AMPs are consistently induced and localized on the cell 
surface during a prolonged time of infection with this pathogenic fungus (Adomas et al. 2007). The $S p$ - $A M P$ genes were further found to be up-regulated in the presence of non-pathogenic (saprotrophic and mutualistic/beneficial) fungi, although the up-regulation did not persist beyond the early stages of exposure (Adomas et al. 2008). At least five genes were found by Southern blotting of Hind III-digested pine genomic DNA (Asiegbu et al. 2003), of which four (Sp-AMP14, with 93-100\% nucleotide sequence identity) have been deposited in the National Center for Biotechnology Information (NCBI) sequence databases; these sequences code for cysteine-rich proteins including an $\mathrm{N}$-terminal region with the characteristics of a cleavable signal peptide. The proteins belong to the conserved MiAMP1 family, which are implicated in the defence of gymnosperms against fungal pathogens (Manners 2009). However, the mode of action and in vivo regulation of such AMPs has so far remained unknown.

In the present study, we present new data on the expression of $S p$ - $A M P$ genes, as well as evidence that the encoded proteins bind to important fungal cell wall components, specifically $\beta$ (1,3)-linked glucans.

\section{Materials and Methods}

\section{Host plants and growth conditions}

Pinus sylvestris seeds (FP-45 Sweden) were surface sterilised with $33 \% \mathrm{H}_{2} \mathrm{O}_{2}$ for 15 min, rinsed in several changes of sterile distilled water, sown on $1 \%$ water agar and incubated at $18^{\circ} \mathrm{C}$ with a photoperiod of $16 \mathrm{~h}$. After 14 days, the resulting seedlings were used for inoculation and treatments described below. 


\section{Fungi and inoculation}

H. annosum (isolate Dragstjard 05044, courtesy of K. Korhonen, Finland), Stereum

sanguinolentum (isolate FBCC1148, Fungal Biotechnology Culture Collection (FBCC), University of Helsinki, Finland) and Lactarius rufus (isolate from the Finnish Forest Research Institute (METLA), Finland), were grown in liquid Hagem medium (Stenlid 1985) for 21 days under static conditions. The mycelia were washed with sterile distilled water and subsequently homogenized for $60 \mathrm{~s}$ in a sterile Waring blender.

Ten $P$. sylvestris seedlings were transferred to sterile filter paper layered on top of $1 \%$ water agar in Petri dishes. The roots were inoculated with $1 \mathrm{ml}$ of the mycelial homogenate and covered with a second moist, sterile filter paper. The plate was sealed with Parafilm and the region of the dish containing the roots was covered with aluminium foil. The seedlings were then incubated at $18^{\circ} \mathrm{C}$ with a photoperiod of $16 \mathrm{~h}$. Control plants were mock-inoculated with $1 \mathrm{ml}$ of sterile distilled water. Three biological replications with three technical replicates of Scots pine seedlings were plated for each fungal inoculation, as well as for control plants; roots were harvested at 1 and 5 days post-inoculation, ground in liquid nitrogen and stored at $-80{ }^{\circ} \mathrm{C}$ prior to RNA extraction.

In a parallel experiment, Scots pine roots were inoculated with yeast (Saccharomyces cerevisiae) mutant strains with reduced levels ( $25 \%$ of the wild type) of chitin $(\Delta c h s 5$ mutant; strain BY4741; genotype Mat a; his3 $\Delta 1$; leu2 $\Delta 0$; met15 $\Delta 0$; ura3 $\Delta 0$; YLR330w::kanMX4; accession number Y05239 (Santos et al. 1997)), or increased levels of $\beta$-(1,6)-glucan where $\beta$-(1,3)-glucan 
and other cell wall components are unaffected ( $\Delta \operatorname{exg}$ mutant; BY4741; Mat a; his $3 \Delta 1$; leu2 $\Delta 0$; met15 $\Delta 0$; ura3 $\Delta 0$; YLR300w::kanMX4; accession number Y05210 (Cappellaro et al. 1998)), as well as their isogenic wild type (BY4741; Mat a; his $3 \Delta 1$; leu2 $\Delta 0$; met 15 $\Delta 0$; ura3 $\Delta 0$; accession number Y00000). All the yeast strains were obtained from EUROSCARF (the European Saccharomyces cerevisiae Archive for Functional Analysis). The yeast were grown in $250 \mathrm{ml}$ liquid culture flasks containing $50 \mathrm{ml}$ of nutrient yeast dextrose broth for $16 \mathrm{~h}$ at $28^{\circ} \mathrm{C}$ on a rotary shaker at $200 \mathrm{rpm}$. Cells were collected by centrifuging at 7,000 g for $10 \mathrm{~min}$, washed twice with sterile distilled water to remove the growth medium, then diluted with sterile distilled water. Roots were inoculated with $1 \mathrm{ml}$ of wild type or mutant yeast cell suspension.

\section{Protoplast generation}

Mycelia of static (3-week) fungal cultures in Hagem medium were mixed, homogenised and centrifuged at 2,600 $\mathrm{g}$ for $5 \mathrm{~min}$ at room temperature. The supernatant was discarded, and the mycelial homogenate washed with $10 \mathrm{ml}$ buffer ( $0.5 \mathrm{M}$ mannitol, $50 \mathrm{mM}$ maleate). Lysing enzymes from Trichoderma harzianum (Sigma-Aldrich, L-1412) were added to homogenised mycelia, and incubated with gentle shaking at $37^{\circ} \mathrm{C}$ for $3.5 \mathrm{~h}$. The resulting protoplasts were filtered through Miracloth (Sigma-Aldrich), centrifuged at 1,500 $\mathrm{g}$ for $10 \mathrm{~min}$, washed three times with $10 \mathrm{ml} \mathrm{MMC} \mathrm{buffer} \mathrm{(} 0.5 \mathrm{M}$ mannitol, $50 \mathrm{mM}$ maleate, $50 \mathrm{mM} \mathrm{CaCl} 2)$ and resuspended in the same buffer. Control plants were mock-inoculated with $10 \mathrm{ml}$ of the MMC buffer. Roots were exposed to protoplasts for $24 \mathrm{~h}$ at $18{ }^{\circ} \mathrm{C}$ with a photoperiod of $16 \mathrm{~h}$.

\section{Hormone treatment}


Scots pine roots were treated with $5 \mathrm{mM}$ salicylic acid (SA), $100 \mathrm{mM}$ methyl jasmonate (MeJA) or $0.5 \mathrm{mM}$ ethylene precursor (1-aminocyclopropane-1-carboxylic-acid, ACC). All chemicals were obtained from Sigma-Aldrich Ltd and dissolved in $0.1 \%$ ethanol; control plants were treated with an equivalent amount of $0.1 \%$ ethanol. In a separate experiment, roots were treated with $1 \mathrm{mM} \mathrm{H}_{2} \mathrm{O}_{2}$; control plants were mock-treated with sterile distilled water. Treated seedlings were incubated for $24 \mathrm{~h}$ at $18^{\circ} \mathrm{C}$ with a photoperiod of $16 \mathrm{~h}$. Three biological replications of $P$. sylvestris roots, consisting of 25 seedlings of either hormone-treated or control plants, were collected and frozen in liquid nitrogen for RNA isolation.

\section{Chitosan, chitin and glucan for fungal studies}

Chitosan flakes from shrimp shells (Sigma-Aldrich, C3646) were prepared according to an earlier procedure (Benhamou and Thériault 1992). Briefly, it was ground to a powder, washed repeatedly in distilled water, pelleted by low speed centrifugation, and air-dried. Sheets of the dried chitosan were solubilized by stirring in $0.25 \mathrm{M} \mathrm{HCl}$, centrifuged at 13,000 $\mathrm{g}$ for $10 \mathrm{~min}$ at 4 ${ }^{\circ} \mathrm{C}$ to remove insoluble material, and precipitated by neutralization with $2.5 \mathrm{M} \mathrm{NaOH}$. Chitosan pellets, recovered by centrifugation at $25,000 \mathrm{~g}$ for $15 \mathrm{~min}$, were thoroughly washed with deionized water to remove salts, then freeze-dried. For use, purified chitosan was dissolved in $0.05 \mathrm{M} \mathrm{HCl}$ under continuous stirring to obtain a stock solution of $1 \mathrm{mg} \cdot \mathrm{ml}^{-1}$; the $\mathrm{pH}$ was adjusted to 5.6 with $1 \mathrm{M} \mathrm{NaOH}$. A 30- $\mu$ l sample of chitosan solution was applied to each seedling root. Chitin (Sigma, C-4666) was washed with sterile water and homogenized for $60 \mathrm{~s}$ in a sterile Waring blender. Each root sample was treated with $100 \mu$ of chitin homogenate (1 $\left.\mathrm{mg} \cdot \mathrm{ml}^{-1}\right)$. Glucan (as laminarin, which consists primarily of poly $(\beta-(1,3)-\mathrm{D}$-glucose, with some $\beta-(1,6)$ inter-strand linkages and branch points) was derived from Laminaria digitata; (Sigma- 
Aldrich L9634)). A 30- $\mu$ l sample of this glucan solution $\left(1 \mathrm{mg} \cdot \mathrm{ml}^{-1}\right)$ was applied to each seedling root. There were three biological replications harvested at 1 and 5 days post-inoculation, ground in liquid nitrogen and stored at $-80{ }^{\circ} \mathrm{C}$ prior to RNA extraction.

\section{RNA extraction and Northern analysis}

RNA was extracted from the roots as described elsewhere (Chang et al. 1993). RNA

concentration and quality were assessed spectrophotometrically using a NanoDrop ${ }^{\mathrm{TM}}$ ND-1000 (NanoDrop Technologies, Wilmington, DE, USA). Northern analyses were performed according to standard protocols (Sambrook and Russell 2001). Total RNA (15 $\mu \mathrm{g})$ sampled from inoculated pine roots at two time points ( 1 and 5 days post-inoculation) was denatured and electrophoresed on a formaldehyde-agarose gel, transferred to a nylon membrane (Amersham Hybond $\mathrm{N}+$ ) by capillary blotting overnight, then fixed to the membrane by baking at $80{ }^{\circ} \mathrm{C}$ for $2 \mathrm{~h}$. Membranes were hybridised with chemifluorescently labelled $S p-A M P$ cDNA as a probe. Labelling was performed using an AlkPhos Direct ${ }^{\mathrm{TM}}$ labelling kit (RPN3680) according to the manufacturer's instructions (Amersham Biosciences). After post-hybridisation washes, membranes were exposed to film for autoradiographic detection.

DNase treatment and cDNA synthesis by reverse transcription A 1- $\mu \mathrm{g}$ sample of each total-RNA isolate was DNase treated using a commercially available kit (RQ1 RNase-free DNase reagents, Promega) according to the manufacturer's instructions. A 1- $\mu$ l aliquot of random hexamers (200 ng, Promega) was added to the treated RNA, after which the sample was heated to $70{ }^{\circ} \mathrm{C}$ for $10 \mathrm{~min}$, then quickly cooled on ice. First strand cDNA synthesis was performed in the presence of $200 \mathrm{U}$ MLV-reverse transcriptase (Promega) for $1 \mathrm{~h}$ at $37{ }^{\circ} \mathrm{C}$. 
The mixture contained $5 \mathrm{x}$ MLV buffer, $10 \mathrm{mM}$ DTT, $10 \mathrm{mM}$ of each dNTP and $20 \mathrm{U}$ RNasin ${ }^{\circledR}$ (Promega) in a volume of $20 \mu \mathrm{l}$; the reaction was stopped by heating at $70{ }^{\circ} \mathrm{C}$ for $10 \mathrm{~min}$.

\section{Real-time quantitative PCR analysis}

Real-time quantitative reverse transcription PCR (qRT-PCR) was performed with the LightCycler® 480 system according to the manufacturer's instructions. Primers targeted the conserved region of the $S p$-AMP family (5'-CCTTCTGAGGGCAGTTATTTCACT-3' (forward) and 5'-CGCGCAGCATGGTTGTTA-3' (reverse)). Sp-AMP amplicon (62 bp) was amplified from synthesized cDNA, separated by electrophoresis in a 3\% agarose gel, and visualized by staining with ethidium bromide. Predicted product size was verified with a $100 \mathrm{bp}$ ladder of DNA markers before analysis with qRT-PCR. The transcript abundance was estimated with LightCycler software version 3.5 (Roche) using SYBR® Green PCR Master Mix (Invitrogen) according to the manufacturer's recommendations, based on three biological and three technical replicates using a standard curve (User Bulletin \#2, ABI Prism 7700 Sequence Detection System, Applied Biosystems). The melting curve analysis indicated a single amplicon for all the samples used in the study. Melting temperatures $\left(\mathrm{T}_{\mathrm{m}}\right)$ were in the range of $82.50-83.25^{\circ} \mathrm{C}$. The absolute quantity of the product in each sample, as deduced from the standard curve, was normalized against the total amount of RNA (Hashimoto et al. 2004; Silberbach et al. 2005). Relative expression levels of the $S p$-AMP genes were determined as described earlier (Livak and Schmittgen 2001).

Cloning, expression of Sp-AMP in Pichia pastoris, and protein purification A more detailed description of these procedures is included in the Supplementary Materials. 
Primers for expression of $S p-A M P 3$ (GenBank accession number AF410954) in P. pastoris were designed considering differences in codon usage between bacterial and yeast systems. PCR was first performed on a pre-existing pET21 plasmid containing $S p$ - $A M P 3$ DNA (Sooriyaarachchi et al, unpublished results), to obtain the mature $S p-A M P 3$ sequence bounded by Xho1 and Kpn1 cleavage sites. The Xho1-Kpn1 fragment was ultimately inserted into the Pichia expression vector pPICZ $\alpha \mathrm{B}$ (Invitrogen) in-frame with the N-terminal secretory peptide of the $S$. cerevisiae $\alpha$-factor. The pPICZ $\alpha \mathrm{B}$ derivatives were transformed into E. coli Top10F' cells. Purified plasmids containing $S p$-AMP3 were linearized with SacI and transformed into the Pichia strain KM71 by electroporation. Transformants were screened for Zeocin resistance at $100 \mu \mathrm{g} \cdot \mathrm{ml}^{-1}$. Colony PCR was performed to confirm the target DNA's recombination into the yeast chromosome. The final yeast strain was maintained on YPD agar plates $(1 \%(\mathrm{w} / \mathrm{v})$ yeast extract, $2 \%(\mathrm{w} / \mathrm{v})$ peptone, $2 \%$ dextrose and $2 \%$ agar) with $100 \mu \mathrm{g} \cdot \mathrm{ml}^{-1}$ Zeocin.

After cleavage of the 89-residue secretory peptide, the 79-residue Sp-AMP3 was secreted when the transformed Pichia strain was induced with methanol. The medium from a 11 induced culture was clarified by centrifugation, and treated with $65 \%(\mathrm{w} / \mathrm{v})$ ammonium sulfate; the precipitated protein was resuspended in $10 \mathrm{mM}$ HEPES, $\mathrm{pH}$ 7.0. After dialysis, the sample was further purified by cation exchange and size exclusion chromatography, and stored in $10 \mathrm{mM}$ HEPES, $\mathrm{pH} 7.0$, at $-20^{\circ} \mathrm{C}$. The amino acid sequence of Sp-AMP3 was confirmed by analyzing an excised gel band by MALDI-TOF mass spectroscopy after trypsin digestion.

To enable affinity purification, a second construct was made including a His tag (AHHHHHH) at the C-terminal end of the Sp-AMP3 sequence. Again, the secreted protein was fractionated by 
ammonium sulfate precipitation, after which it was dialyzed against $20 \mathrm{mM}$ sodium phosphate, $\mathrm{pH}$ 7.6. The concentrated sample was subsequently purified by chelating and size exclusion chromatography. Fractions containing pure protein were concentrated and stored in $10 \mathrm{mM}$ HEPES buffer, $\mathrm{pH} 7.0$, at $-20^{\circ} \mathrm{C}$.

\section{Binding assays}

For binding assays with insoluble carbohydrate polymers, $30 \mu 1$ of a $0.75 \mathrm{mg} \cdot \mathrm{ml}^{-1}$ protein solution was incubated at $4{ }^{\circ} \mathrm{C}$ for $6 \mathrm{~h}$ with a $2 \mathrm{mg}$ sample of dry chitin, chitosan (both the kind gift of Kitto Life Co. Ltd, Seoul, Korea) or curdlan ( $\beta$-(1,3)-D-glucan from Alcaligenes faecalis, Sigma-Aldrich C7821). The samples were then centrifuged for $10 \mathrm{~min}$ at $16,000 \mathrm{~g}$. The supernatant in each case was reserved, and the pellets were washed with $30 \mu 1$ of $10 \mathrm{mM}$ HEPES buffer, $\mathrm{pH} 7.0$, then with $30 \mu \mathrm{l}$ of $1 \mathrm{M} \mathrm{NaCl}$ in $10 \%$ acetic acid $\left(10\right.$ min at $\left.4{ }^{\circ} \mathrm{C}\right)$, each time recovering the supernatant after centrifugation. SDS-PAGE was performed to determine the fractions in which the protein appeared.

Binding of soluble sugars was monitored using changes in protein tryptophan fluorescence in an SPF-500 spectrofluorometer (Aminco) at $25^{\circ} \mathrm{C}$. Sp-AMP3 samples $(1 \mathrm{ml}$ of $0.5 \mu \mathrm{M}$ protein in 10 mM HEPES, $\mathrm{pH}$ 7.0) were treated with a series of $10-\mu 1$ aliquots of sugar solution (glucose, laminarioligosaccharides from laminaribiose up to laminarihexose, glucan (laminarin), cellobiose, cellotriose or cellopentaose, all obtained from Sigma-Aldrich, and prepared as 2 $\mathrm{mg} \cdot \mathrm{ml}^{-1}$ stocks in the same buffer). The solution was mixed well, and equilibrated at room temperature. Emission spectra were recorded with a fixed excitation wavelength of $285 \mathrm{~nm}$; excitation and emission slits were 10 and $8 \mathrm{~nm}$, respectively. 


\section{Determination of antifungal activity}

Antifungal activity of Sp-AMP3 was studied by observing H. annosum (strain FP5) growth on Hagem agar plates $\left(0.5 \%\right.$ glucose, $0.05 \% \mathrm{NH}_{4} \mathrm{NO}_{3}, 0.05 \% \mathrm{KH}_{2} \mathrm{PO}_{4}, 0.05 \% \mathrm{MgSO}_{4} .7 \mathrm{H}_{2} \mathrm{O}, 0.5 \%$ malt extract, $2.0 \%$ agar, $\mathrm{pH} 5.5$ ). To initiate mycelial growth, an agar plug containing $H$. annosum was placed at the center of a Petri dish containing $20 \mathrm{ml}$ of the medium, and incubated in the dark at room temperature until the mycelia reached a diameter of $3 \mathrm{~cm}$. A sterilized filter

paper disc containing $10 \mu \mathrm{l}$ of $0.75 \mathrm{mg} \cdot \mathrm{ml}^{-1}$ protein solution (with or without His-tag) was placed at the growth front. Controls included a concentrated sample of the growth medium collected before induction, as well as the protein storage buffer (10 mM HEPES, $\mathrm{pH}$ 7.0). The plates were incubated further in the dark and observed at intervals.

Inhibition of spore germination was investigated after spreading a spore suspension (in sterilized water) evenly on Hagem agar plates. Protein solutions were added to sterilized filter paper disks, which were placed on the plates, followed by incubation in the dark at room temperature for one week. Addition of $10 \mu \mathrm{l}$ of $0.75 \mathrm{mg} \cdot \mathrm{ml}^{-1}$ protein or control solution was repeated every $24 \mathrm{~h}$.

Sequence alignment and homology modeling of Sp-AMP3

Similar sequences were located using BLAST (Altschul et al. 1997) and obtained from GenBank (Benson et al. 2011). The most similar structure, that of the Macadamia integrifolia protein MiAMP1 solved by NMR (PDB entry 1C01 (McManus et al. 1999)), was obtained from the PDB (Berman et al. 2000); the first of the 20 deposited models was used in further work. Pairwise alignment of the Sp-AMP4 and MiAMP1 sequences with CLUSTAL W (Thompson et al. 
1994) was used to create a homology model with the program SOD (Kleywegt et al. 2001). The model was adjusted in O (Jones et al. 1991) using rotamers to improve packing as needed. Similar structures were located with DALI (Holm 1998). Figures were prepared with O, Molscript (Kraulis 1991) and Molray (Harris and Jones 2001). Stereo glasses (stereoscopes) for viewing diagrams such as that in Fig. 7 are available from, for example, ASC Scientific (Carlsbad, CA, USA).

\section{Results}

Sp-AMP expression in response to pathogen, non-pathogen or fungal protoplast exposure Expression of $S p-A M P$ genes was investigated in Scots pine challenged with pathogenic $(H$. annosum), mutualistic/beneficial (L.rufus) or saprotrophic (S. sanguinolentum) fungi, all belonging to the same basidiomycete group, Russulales. Northern analysis at 1 day revealed no significant differences in $S p$-AMP expression when the plants were challenged with the three fungi (Fig. 1a). $S p-A M P$ expression over a longer period of infection (5 days post-inoculation) was much higher with the pathogenic fungi than with either mutualistic or saprotrophic fungi, both of which were only modestly increased over the control. Expression of $S p-A M P$ was further investigated using the more sensitive and quantitative real-time qRT-PCR (Fig. 1b), which actually showed an initial decrease, then a large increase in $S p-A M P$ expression during infection with the pathogenic fungus. Small increases were observed at 1 day after challenge with the mutualistic and saprotrophic fungi, which had not significantly changed at 5 days post-infection. To test whether the presence of the fungal cell wall is essential for initial recognition and for $S p$ $A M P$ up-regulation, homogenized mycelia of the various fungi were treated with cell-wall 
degrading enzymes to generate protoplasts, which are expected to be devoid of the cell wall. Protoplasts generated from either pathogenic or mutualistic fungi induced high levels of $S p-A M P$ expression in Scots pine roots, while those from saprotrophic fungi did not (see Fig. 1c).

\section{Effects of exogenous application of SA, MeJA and ACC on Sp-AMP expression}

To investigate the role of MeJA-, SA-, ethylene- and $\mathrm{H}_{2} \mathrm{O}_{2}$-responsive pathways in regulating $S p-A M P$ expression, roots of Scots pine were treated with the respective compounds. The results from qRT-PCR revealed up-regulation of $S p-A M P 1$ day after treatment with SA or ACC. Neither MeJA nor $\mathrm{H}_{2} \mathrm{O}_{2}$ induced expression of $S p-A M P$, and indeed, $\mathrm{H}_{2} \mathrm{O}_{2}$ caused a decrease (Fig. 2).

\section{Cloning and expression of $S p-A M P 3$}

Extensive efforts to obtain expression of soluble protein in a number of cytoplasmic and secreted E. coli systems were unsuccessful, as were countless refolding experiments with inclusion bodies (unpublished data). Sp-AMP3 protein was eventually produced in a Pichia system. While yields of pure protein were low at best ( $\sim 0.4 \mathrm{mg}$ of $99 \%$ pure protein per liter of induced culture) and extremely variable, sufficient quantities were obtained to allow several key functional studies. As detailed in the Supplementary Materials, the correctness of the protein obtained was verified by tryptic peptides identified by mass spectroscopic analysis, which included the $\mathrm{N}$-and $\mathrm{C}$-terminal ends of the Sp-AMP3 sequence. 
Sp-AMP3 strongly inhibited both hyphal growth and spore germination of H. annosum (Fig. 3). Addition of $10 \mu \mathrm{g} \cdot \mathrm{ml}^{-1}$ Sp-AMP3 caused nearly complete inhibition during a 3-day incubation period. Controls (samples taken before induction, in the same buffer as the protein sample, as well as the buffer itself) did not inhibit mycelial growth or spore germination. Sp-AMP3 samples with and without His-tags had equivalent effects on the fungal growth.

Binding of fungal cell-wall polysaccharides to Sp-AMP3

Sp-AMP3 did not bind to insoluble chitin and chitosan, with most of the protein remaining in the supernatant when the protein was incubated with either of these polysaccharides (see Fig. 4a). By contrast, treatment of the Sp-AMP3 solution with curdlan (an insoluble $\beta$-(1,3)-D-glucan) resulted in strong binding; there was no protein evident in the initial supernatant or in the wash with buffer, while the majority of the Sp-AMP3 was denatured/released with $\mathrm{NaCl} /$ acetic acid.

The binding of soluble sugars to Sp-AMP3 could be detected using the fluorescence change of at least one tryptophan residue of the protein when sugar bound. The ligands tested included $\beta$ (1,3)-glucan sugars ranging from laminaribiose up to laminariheptaose, glucan (laminarin), glucose, cellobiose, cellotriose and cellopentaose. The sugars did not themselves fluoresce in the absence of Sp-AMP3. Only sugars containing $\beta$-(1,3)-glucan (i.e. the laminarioligosaccharides and laminarin) were found to bind significantly, as illustrated for laminaribiose in Fig. 4b; additional results are shown in the Supplementary Materials. None of the other sugars tested (including glucose) caused any change in the fluorescence signal. 
To investigate the effect of fungal cell wall components on $S p-A M P$ expression and regulation, we monitored the responses of Scots pine seedlings after treatment with chitin, chitosan or glucan (laminarin). All three compounds provoked strong discoloration in the roots at 5 days post-inoculation, although glucan treatment provoked the greatest response at both 1 and 5 days (Fig. 5a). Analyses of $S p-A M P$ expression by qRT-PCR showed a 2-fold induction of $S p$ - $A M P \mathrm{~S}$ expression at a very early stage after glucan treatment, which persisted over time (Fig. 5b). The qRT-PCR analysis also revealed that chitin and chitosan suppressed $S p$-AMP expression.

Effects of yeast mutants on Sp-AMP expression

The qRT-PCR analysis showed that inoculation with yeast mutants having $\sim$-fold reduced levels of chitin ( $\Delta$ chs 5 mutant; (Santos et al. 1997)) or increased levels of $\beta-(1,6)$-glucan $(\Delta e x g$ mutant (Cappellaro et al. 1998)) both caused an increased transcription of $S p-A M P$ genes in Scots pine roots relative to the wild type yeast control, at 5 days post-inoculation (Fig. 6). Inoculation with $\Delta$ exg yeast induced the expression of $S p$ - $A M P$ s 4 -fold, compared to the 2-fold increase with $\Delta c h s 5$ yeast, at this time point. At a very early stage, there was no significant differential expression with $\Delta c h s 5$ compared to the wild type yeast inoculation, but a significant reduction in $S p-A M P$ transcript abundance was seen with the $\Delta$ exg mutant (Fig. 6).

\section{Sequence alignment and homology modeling}

Differences among the four sequenced Sp-AMPs are very small. Sp-AMP1 differs from the other three Sp-AMPs by virtue of only 5-6 amino acid changes in the 79-residue mature protein (i.e. $\sim 93 \%$ identity). Sp-AMP2 and Sp-AMP4 are identical even at the level of the DNA sequence, and differ from Sp-AMP3 at a single amino-acid position (residue 44 of the mature protein is 
serine in Sp-AMP1 and Sp-AMP3, and alanine in Sp-AMP2 and Sp-AMP4). For these reasons, only Sp-AMP1 and Sp-AMP2 sequences are shown in Fig. 7a.

Other sequences identified in a BLAST search represent mostly plant proteins with amino-acid identities of at least 39\% over the entire Sp-AMP sequence. A number of fungal proteins are also found, with similar levels of sequence identity, although not covering the first 16 residues. One example is highlighted in Fig. 7a, the protein from Aspergillus fumigatus, but others (with 67\% or greater identity to the A. fumigatus protein) have been reported in Uncinocarpus reesii, Neosartorya fischeri and Aspergillus clavatus; a protein from Penicillium chrysogenum is somewhat more distant. Residues that are strongly conserved among the plant proteins are also well represented in these fungal sequences. The Heterobasidion genome (publically available at http://genome.jgi-psf.org/Hetan2/Hetan2.home.html), however, does not appear to contain equivalent proteins. The genomes of $L$. rufus and $S$. sanguinolentum are not yet available.

The only structure located by a BLAST search is that of MiAMP1 (solved by NMR, PDB entry $1 \mathrm{C} 01 ; 68 \%$ amino acid identity to Sp-AMP3), an antimicrobial protein from macadamia with unknown mode of action. A homology model of Sp-AMP3 based on MiAMP1 is illustrated in Fig. $7 \mathrm{~b}$, allowing the conservation of various residues in the plant proteins to be placed in a structural context. The largest cluster of conserved surface residues lies on a flat face of the protein near Tyr46, as shown in Fig. 7c and d.

Structural similarity searches with DALI (Holm 1998) using the MiAMP1 structure identified a number of additional proteins of interest (Z-scores of 4-7) belonging to the gamma-crystallin-like 
superfamily of SCOP (Murzin et al. 1995); these have a fold similar to Sp-AMPs and MiAMP1, but generally less than $15 \%$ sequence identity with them. Examples include the killer toxin secreted by the yeast Williopsis mrakii (PDB entry 1WKT), as well as bacterial proteins such as Streptomyces spp. killer toxin-like protein (PDB entry 1F53) and an anti-fungal protein from Streptomyces tendae Tü901 (PDB entry 1G6E). The MiAMP1 comparison with the W. mrakii protein, for instance, gives a DALI Z-score of 4.5, a root-mean-square difference of $2.6 \AA$ over $72 \%$ of the $\alpha$-carbons of the protein, and an amino-acid identity in the matched regions of the sequence/structure of $13 \%$.

\section{Discussion}

In this study, roots from Scots pine seedlings were used to study fungal-conifer interactions. The validity of using seedling roots as an experimental model for $H$. annosum infection has been addressed previously (Asiegbu et al. 1994). During development, the conifer root undergoes several morphological and physiological transformations. The non-suberized seedling roots are gradually suberized, as the cortex disappears and the secondary xylem in the vascular region (stele) becomes dominant. Later, the epidermis, cortex and endodermis are replaced by the rhytidome, phelloderm and phloem layers. These morphological changes occur in parallel with constitutive and inducible defence responses. H. annosum is one of very few fungal pathogens able to infect conifer roots of all ages (Asiegbu et al. 1993). In our experimental model, seedlings are grown under controlled, sterile conditions, and used at an age when their genetic differences are not strongly expressed, thus increasing the efficiency and reproducibility of the testing protocol. 
Scots pine roots responded differently when they were exposed to three Russulales fungi belonging to distinct ecological functional groups. $S p$ - $A M P$ expression was induced slightly upon the first physical encounter with the saprotrophic or mutualistic fungi, but not with the pathogen. By contrast, with prolonged incubation, the $S p-A M P$ gene was significantly expressed only in response to the pathogen (Fig. 1). The differential expression shows that the host is able to distinguish among the diverse lifestyles of the inoculated fungi, and suggests a role for Sp-AMPs in defence. These results confirm and extend earlier work with more distantly related fungi (Adomas et al. 2008), which included both saprotrophs, which derive their nutrients from the surrounding dead organic matter, and symbiotic fungi, which depend on the living plant host for carbon. In contrast to these two types of fungi, H. annosum is capable of invasive growth into host cells. AMP induction is in fact occurring on a timescale similar to that observed for the pathogen's invasion into the plant tissues (Asiegbu et al. 1994; Li and Asiegbu 2004). The delay in $S p$-AMP expression during challenge with pathogenic fungi suggests the possibility of some form of masking by the invading fungus as a means to evade host defences (Jones and Dangl 2006). Protoplasts from both pathogenic and mutualistic/beneficial, but not saprotrophic, fungi induced strong $S p-A M P$ expression (Fig. 1c), indicating that factors other than cell-wall components can also trigger the process, possibly including molecules secreted by the fungal cells. However, we are at present unable to explain the different responses observed when pine roots were inoculated with protoplasts versus mycelial homogenate from the mutualistic fungus. It is possible that the protective cell wall of the mutualist fungus includes components that regulate the course of symbiosis as well as the nature/pattern of associated host responses. 
The crucial roles plant hormones play in regulating developmental processes, as well as responses to a wide range of biotic and abiotic stresses, have been reviewed elsewhere (Bari and Jones 2009). Sp-AMPs were shown here to be up-regulated after a 1-day treatment with SA or the ethylene precursor, ACC, but not with MeJA or $\mathrm{H}_{2} \mathrm{O}_{2}$ (Fig. 2). The accumulation of SA in response to elicitors and pathogen challenge was earlier shown in pine (Davis et al. 2002). SA is furthermore known to induce specific sets of PR genes (Pieterse and van Loon 1999) prior to the establishment of systemic acquired resistance (Grant and Lamb 2006). In contrast to the results with Sp-AMP, expression of Pm-AMP1, a homolog in western white pine (Pinus monitcola) that is involved in defence against the blister rust fungus Cronartium ribicola, is induced in healthy foliage 4 days after MeJA treatment (Ekramoddoullah et al. 2006). The longer incubation time before sampling may explain the different outcomes; it is also possible that the defence signalling network activated by the plant is dependent on the nature of the pathogen and its mode of pathogenicity (reviewed by (Bari and Jones 2009)) . The induction of $S p-A M P$ by ACC suggests the involvement of ethylene in $S p$ - $A M P$ regulation during biotic and abiotic stress. Ethylene signalling has been implicated in induced cellular and chemical defences in conifers, and is vital in the activation of cells specialized for the formation of defence-related terpenoids and phenolics in the outermost bark and phloem tissues (Hudgins et al. 2006).

The similarity of the four known Sp-AMP sequences (93-100\% amino acid sequence identity, Fig. 7a) strongly suggests that all have similar structure and biological function. Homology modeling based on the NMR structure of the macadamia antimicrobial protein, MiAMP1 (68\% identity), indicated that proteins of this type possess a Greek-key $\beta$-barrel fold, as illustrated in Fig. $7 b$. The absence of a pocket or cleft indicates that enzymatic activity is unlikely, and so a 
binding function was expected. The content of negatively-charged residues in the AMPs is strikingly low ( $\sim 2 \%$, compared to a more usual value of $\sim 12 \%$, e.g. http://expasy.org/sprot/relnotes/relstat.html), which leads to pIs of 8.5 or more. However, no clustering of the positively charged residues is seen on the surface that would suggest binding of negatively-charged ligands (such as many membrane lipids). Obtaining Sp-AMP for direct biological and biochemical tests was viewed as a crucial next step. However, numerous strategies for E. coli expression produced only large quantities of insoluble protein, which we could not refold (unpublished data). Experiments with Pichia pastoris were more successful. Although the yield of soluble Sp-AMP3 was extremely variable and very low at best, sufficient material was obtained to demonstrate that the protein did possess antifungal activity (Fig. 3), and had marked effects on fungal hyphae and spores (Sooriyaarachchi et al., unpublished microscopic studies). To test the hypothesis that the biological function involves some component of the fungal cell wall, our assays of binding activity included the main compounds in that structure, as well as those in plant cell walls. The results showed that $\beta$-glucan sugars, in both soluble and insoluble forms, bind to Sp-AMP3, while sugars from the chitin, chitosan and cellulose classes did not (Fig. 4). Residues strongly conserved in plant sequences are clustered on a flat face on the AMP surface, forming a patch that is of sufficient size to bind at least four, but no more than six, sugar units in a $\beta-(1,3)$-glucan molecule (Fig. 7c and d); two of the three conserved disulfide bonds (Cys21-Cys79 and Cys23-Cys51) help maintain its shape. This surface includes polar residues, as well as two aromatics (Tyr46 and Phe76). Consideration of the homology model also suggests that the change in fluorescence seen when soluble sugars are bound reflects a (probably quite small) change in the overall protein structure, as neither of the 
tryptophans of the sequence (Trp6 and Trp72) is expected to be exposed on the putative binding surface, and so they will not make direct contact with a bound ligand (Fig. 7d).

Our experiments have thus revealed that the Sp-AMPs represent a novel family of $\beta$-glucan binding proteins. Because of their antimicrobial properties, increased expression in response to pathogen challenge, and presence in a wide variety of plants (as reviewed elsewhere (Manners 2009)), we believe they define a new PR family, PR-19. We note that PR-2 comprises $\beta-(1,3)-$ endoglucanases, but to date no PR family has been linked to the non-catalytic role of glucan binding. Earlier anti-glucanase immunogold labeling experiments demonstrated that glucans are accessible in Heterobasidion cell walls (Asiegbu et al. 1995), and so are a biologically reasonable target for PR-19 proteins. The discovery that glucans are ligands of interest also suggests that problems in heterologous expression were due to counterproductive interactions between Sp-AMPs and the expression hosts tested. Alternate expression systems will be explored in future work. The availability of additional protein will allow us to investigate many interesting aspects of the Sp-AMP structure and function that are presently unclear.

In agreement with studies of the protein, addition of exogenous $\beta$-glucan induces $S p$ - $A M P$ expression, but addition of chitosan and chitin does not (Fig. 5). The fact that mutants with increased $\beta$-(1,6)-glucan (Jiang et al. 1995), but normal levels of $\beta$-(1,3)-glucan and chitin, induced $S p-A M P$ expression suggests a role for other structural forms of glucan (Fig. 6).

Structural similarities of the PR-19 proteins to fungal and bacterial ones like the killer protein from the yeast $W$. mrakii are also intriguing. Although the relationships are very distant, the 
killer protein is known to inhibit the action of $\beta-(1,3)$-glucan synthase in sensitive yeast strains, apparently by competing for binding of $\beta$-glucan (Peng et al. 2010). Taken together with our identification of AMP-like sequences in some fungal species (Fig. 7a), this suggests that such proteins are not restricted to plants, but are a fairly widespread way for organisms to protect themselves.. Differences in the fungal cell walls would allow the glucan-binding proteins to act on some organisms, but leave others unscathed. In vulnerable fungi, Sp-AMP binding may, for example, interfere with glucan assembly, which could alter cell wall structure, so causing morphological distortion of hyphae. Effects on glucan could also lead to a weakening of the membrane and compromise cell wall integrity, with the result of unusual spore and hyphal swellings and consequently a burst.

Both our demonstration that recombinant Sp-AMP has a potent inhibitory effect on spore and hyphae development of the conifer pathogen $H$. annosum, as well as evidence that this property can be linked to the binding to major fungal cell wall components (i.e. glucans), provide vital leads for future work. Exploring the practical applications of the Sp-AMPs themselves, further investigation of their spectrum of antimicrobial action, and developing a functional synthetic mimic, will be priorities.

\section{Acknowledgements}

This work was supported by grants from the Swedish Research Council for the Environment, Agricultural Sciences and Spatial Planning (FORMAS) and the Swedish Research Council (VR) to SLM, and from the Academy of Finland (AKA) and the University of Helsinki Research Fund to FOA. We extend our sincere thanks to Christin Hansson, Johan Winquist and Kerstin Ahlgren 
for their heroic attempts at E. coli expression. We also especially thank Prof. Ulf Hellman,

Ludwig Institute for Cancer Research, Uppsala, Sweden for mass spectroscopic analysis, and

Gulaim A. Seisenbaeva, Department of Chemistry, Swedish University of Agricultural Sciences

for help with the scanning electron microscopy.

\section{References}

Adomas A, Heller G, Li GS, Olson A, Chu TM, Osborne J, Craig D, Van Zyl L, Wolfinger R, Sederoff R, Dean RA, Stenlid J, Finlay R, Asiegbu FO (2007) Transcript profiling of a conifer pathosystem: response of Pinus sylvestris root tissues to pathogen (Heterobasidion annosum) invasion. Tree Physiology 27 (10):1441-1458

Adomas A, Heller G, Olson A, Osborne J, Karlsson M, Nahalkova J, Van Zyl L, Sederoff R, Stenlid J, Finlay R, Asiegbu FO (2008) Comparative analysis of transcript abundance in Pinus sylvestris after challenge with a saprotrophic, pathogenic or mutualistic fungus. Tree Physiol 28 (6):885-897

Altschul SF, Madden TL, Schaffer AA, Zhang J, Zhang Z, Miller W, Lipman DJ (1997) Gapped BLAST and PSI-BLAST: a new generation of protein database search programs. Nucleic Acids Res 25 (17):3389-3402

Asiegbu FO, Adomas A, Stenlid J (2005) Conifer root and butt rot caused by Heterobasidion annosum (Fr.) Bref. s.l. Molecular Plant Pathology 6 (4):395-409

Asiegbu FO, Choi W, Li G, Nahalkova J, Dean RA (2003) Isolation of a novel antimicrobial peptide gene (Sp-AMP) homologue from Pinus sylvestris (Scots pine) following infection with the root rot fungus Heterobasidion annosum. FEMS Microbiol Lett 228 (1):27-31

Asiegbu FO, Daniel G, Johansson M (1993) Studies on the infection of Norway spruce roots by Heterobasidion annosum. Canadian Journal of Botany 71:1552-1561

Asiegbu FO, Daniel G, Johansson M (1994) Defense-related reactions of seedling roots of norway spruce to infection by Heterobasidion annosum (Fr.) Bref. Physiological and Molecular Plant Pathology 45 (1):1-19

Asiegbu FO, Denekamp M, Daniel G, Johansson M (1995) Immune Cytochemical-Localization of Pathogenesis-Related Proteins in Roots of Norway Spruce Infected with Heterobasidion annosum. European Journal of Forest Pathology 25 (3):169-178

Bari R, Jones JD (2009) Role of plant hormones in plant defence responses. Plant Mol Biol 69 (4):473-488. doi:10.1007/s11103-008-9435-0

Benhamou N, Thériault G (1992) Treatment with chitosan enhances resistance of tomato plants to the crown and root pathogen Fusarium oxysporum f. sp. radicis-lycopersici. Physiol Mol Plant Pathol (41 ):34-52

Benson DA, Karsch-Mizrachi I, Lipman DJ, Ostell J, Sayers EW (2011) GenBank. Nucleic Acids Res 39 (Database issue):D32-37. doi:10.1093/nar/gkq1079

Berman HM, Westbrook J, Feng Z, Gilliland G, Bhat TN, Weissig H, Shindyalov IN, Bourne PE (2000) The Protein Data Bank. Nucleic Acids Res 28 (1):235-242 
Broekaert WF, Cammue BPA, DeBolle MFC, Thevissen K, DeSamblanx GW, Osborn RW (1997) Antimicrobial peptides from plants. Critical Reviews in Plant Sciences 16 (3):297323

Cappellaro C, Mrsa V, Tanner W (1998) New potential cell wall glucanases of Saccharomyces cerevisiae and their involvement in mating. J Bacteriol 180 (19):5030-5037

Chang S, Puryear J, Cairney J (1993) A simple and efficient method for isolating RNA from pine trees. Plant Molecular Biology Reporter 11:113-116

Davis JM, Wu H, Cooke JE, Reed JM, Luce KS, Michler CH (2002) Pathogen challenge, salicylic acid, and jasmonic acid regulate expression of chitinase gene homologs in pine. Mol Plant Microbe Interact 15 (4):380-387. doi:10.1094/MPMI.2002.15.4.380

Ekramoddoullah AK, Liu JJ, Zamani A (2006) Cloning and Characterization of a Putative Antifungal Peptide Gene (Pm-AMP1) in Pinus monticola. Phytopathology 96 (2):164170. doi:10.1094/PHYTO-96-0164

Grant M, Lamb C (2006) Systemic immunity. Current Opinion in Plant Biology 9 (4):414-420. doi:Doi 10.1016/J.Pbi.2006.05.013

Harris M, Jones TA (2001) Molray - a web interface between O and the POV-Ray ray tracer. Acta Crystallographica Section D-Biological Crystallography 57:1201-1203

Hashimoto JG, Beadles-Bohling AS, Wiren KM (2004) Comparison of RiboGreen and $18 \mathrm{~S}$ rRNA quantitation for normalizing real-time RT-PCR expression analysis. Biotechniques 36 (1):54-56, 58-60

Holm L (1998) Unification of protein families. Curr Opin Struct Biol 8 (3):372-379. doi:S0959440X(98)80072-9 [pii]

Hudgins JW, Ralph SG, Franceschi VR, Bohlmann J (2006) Ethylene in induced conifer defense: cDNA cloning, protein expression, and cellular and subcellular localization of 1aminocyclopropane-1-carboxylate oxidase in resin duct and phenolic parenchyma cells. Planta 224 (4):865-877. doi:Doi 10.1007/S00425-006-0274-4

Jiang B, Ram AF, Sheraton J, Klis FM, Bussey H (1995) Regulation of cell wall beta-glucan assembly: PTC1 negatively affects PBS2 action in a pathway that includes modulation of EXG1 transcription. Mol Gen Genet 248 (3):260-269

Jones JD, Dangl JL (2006) The plant immune system. Nature 444 (7117):323-329. doi:nature05286 [pii]

10.1038 /nature 05286

Jones TA, Zou JY, Cowan SW, Kjeldgaard M (1991) Improved methods for building protein models in electron density maps and the location of errors in these models. Acta Crystallogr A 47 ( Pt 2):110-119

Kleywegt GJ, Zou JY, Kjeldgaard M, Jones TA (2001) Around O. Rossmann, M.G., et al. (Eds.). International Tables for Crystallography, Vol F Crystallography of Biological Macromolecules:pp. 353-356

Kraulis PJ (1991) Molscript - a program to produce both detailed and schematic plots of protein structures. Journal of Applied Crystallography 24:946-950

Li G, Asiegbu FO (2004) Use of Scots pine seedling roots as an experimental model to investigate gene expression during interaction with the conifer pathogen Heterobasidion annosum (P-type). J Plant Res 117 (2):155-162. doi:10.1007/s10265-003-0140-4

Livak KJ, Schmittgen TD (2001) Analysis of relative gene expression data using real-time quantitative PCR and the 2(-Delta Delta C(T)) Method. Methods 25 (4):402-408. doi:10.1006/meth.2001.1262 
S1046-2023(01)91262-9 [pii]

Manners JM (2009) Primitive Defence: The MiAMP1 Antimicrobial Peptide Family. Plant Molecular Biology Reporter 27 (3):237-242. doi:Doi 10.1007/S11105-008-0083-Y

McManus AM, Nielsen KJ, Marcus JP, Harrison SJ, Green JL, Manners JM, Craik DJ (1999) MiAMP1, a novel protein from Macadamia integrifolia adopts a Greek key beta-barrel fold unique amongst plant antimicrobial proteins. J Mol Biol 293 (3):629-638

Montesinos E (2007) Antimicrobial peptides and plant disease control. FEMS Microbiol Lett 270 (1):1-11. doi:FML683 [pii]

10.1111/j.1574-6968.2007.00683.x

Murzin AG, Brenner SE, Hubbard T, Chothia C (1995) SCOP: a structural classification of proteins database for the investigation of sequences and structures. J Mol Biol 247 (4):536-540. doi:10.1006/jmbi.1995.0159

S0022283685701593 [pii]

Peng Y, Chi Z, Wang X, Li J (2010) beta-1,3-glucanase inhibits activity of the killer toxin produced by the marine-derived yeast Williopsis saturnus WC91-2. Mar Biotechnol (NY) 12 (4):479-485. doi:10.1007/s 10126-009-9243-9

Pieterse CM, van Loon LC (1999) Salicylic acid-independent plant defence pathways. Trends Plant Sci 4 (2):52-58

Sambrook J, Russell DW (2001) Molecular Cloning: A Laboratory Manual. Cold Spring Harbor Laboratory Press. Cold Spring Harbor, New York

Santos B, Duran A, Valdivieso MH (1997) CHS5, a gene involved in chitin synthesis and mating in Saccharomyces cerevisiae. Mol Cell Biol 17 (5):2485-2496

Silberbach M, Schafer M, Huser AT, Kalinowski J, Puhler A, Kramer R, Burkovski A (2005) Adaptation of Corynebacterium glutamicum to ammonium limitation: a global analysis using transcriptome and proteome techniques. Appl Environ Microbiol 71 (5):2391-2402. doi:71/5/2391 [pii]

10.1128/AEM.71.5.2391-2402.2005

Stenlid J (1985) Population structure of Heterobasidion annosum as determined by somatic incompatibility, sexual incompatibility and isoenzyme patterns. Can J Bot (63):187-198

Thomma BP, Eggermont K, Penninckx IA, Mauch-Mani B, Vogelsang R, Cammue BP, Broekaert WF (1998) Separate jasmonate-dependent and salicylate-dependent defenseresponse pathways in Arabidopsis are essential for resistance to distinct microbial pathogens. Proc Natl Acad Sci U S A 95 (25):15107-15111

Thompson JD, Higgins DG, Gibson TJ (1994) Clustal-W - Improving the sensitivity of progressive multiple sequence alignment through sequence weighting, position-specific gap penalties and weight matrix choice. Nucleic Acids Res 22 (22):4673-4680

van Loon LC, Rep M, Pieterse CM (2006) Significance of inducible defense-related proteins in infected plants. Annu Rev Phytopathol 44:135-162. doi:10.1146/annurev.phyto.44.070505.143425

van Loon LC, Van Strien EA (1999) The families of pathogenesis-related proteins, their activities, and comparative analysis of PR-1 type proteins. Physiol Mol Plant Pathol 55:85-97 


\section{Figure legends}

Fig. 1. Effects of different functional groups of fungi on transcript abundance of $S p$ - $A M P$ genes. (A) In a Northern blot analysis, total RNA was extracted from roots inoculated with fungi that are pathogenic (H. annosum, P), mutualistic/beneficial (L. rufus, M) or saprotrophic $(S$. sanquinolentum, S), 1 and 5 days post-inoculation. Control seedlings (C) were inoculated with sterile water. (B) qRT-PCR was used to measure transcript abundance of $S p-A M P$ genes. Data represent fold change of transcript abundance of $S p-A M P$ expressed in inoculated seedlings compared to that of control seedlings inoculated with sterile water. (C) The effects of protoplasts generated from the same three fungi were investigated in similar qRT-PCR experiments. Data represent fold change of $S p$-Amp transcript copy number 1 day after inoculation, compared to that of control seedlings mock-inoculated with MMC buffer. Error bars indicate the standard error across three biological replicates.

Fig. 2. Effects of hormone/chemical treatment on transcript abundance of $S p-A M P$ genes. Data represent fold change of $S p$-AMP transcript copy number over that of the control. (A) The effects of MeJA, SA and ACC treatment of Scots pine roots on transcript abundance of $S p-A M P$ genes were measured 1 day after treatments were initiated. cDNAs derived from RNA extracted from roots inoculated with $0.1 \%$ ethanol were used as an endogenous reference. (B) The effects of hydrogen peroxide treatment were measured similarly, except that the reference treatment was sterile water. Error bars indicate the standard error across three biological replicates. 
Fig. 3. Sp-AMP3 inhibition of H. annosum growth and spore germination. In panels (A), (B) and (C), the effects of various samples on H. annosum growth are shown at 2, 3 and 5 days, as follows: a. $10 \mathrm{mM}$ HEPES, b. concentrated medium from the growth phase (before induction) of the transformed Pichia strain including Sp-AMP3 without His-tag, c. purified Sp-AMP3 without His-tag, d. purified Sp-AMP3 with His-tag. Spore germination was investigated in panels (D) and (E), for spores treated with buffer (10 mM HEPES, pH 7.0) or Sp-AMP3 without His-tag, respectively. Spores were incubated for 1 week.

Fig. 4. Binding of Sp-AMP3 to sugars. (A) SDS gels show the results with insoluble sugars, including chitin, chitosan and curdlan. One $\mu 1$ of the relevant sample (prepared as described in the Methods section) was loaded in each lane. A polypeptide marker (PM) is shown (with the components indicated in $\mathrm{kDa}$ ), as well as a low molecular weight marker (LM, from top to bottom, 94, 67, 43, 30, 21 and $14 \mathrm{kDa}$ ). Briefly, Sp-AMP3 bound tightly only to curdlan, requiring a salt-acid wash to release the protein in this case. (B) Fluorescence emission spectra of Sp-AMP3 $(0.5 \mu \mathrm{M})$ in the presence and absence of laminaribiose (final concentration $0.1 \mathrm{mg} \cdot \mathrm{ml}^{-}$ $\left.{ }^{1}=290 \mu \mathrm{M}\right)$ were measured as described in the Methods section. Fluorescence enhancement was associated with the binding of the sugar. The peak near $310 \mathrm{~nm}$ is due to the HEPES buffer, and so provides an internal reference.

Fig. 5. Effects of polysaccharide treatment on Scots pine seedlings. (A) Necrosis in roots pretreated with exogenous glucan (laminarin) is shown at 5 days post-inoculation. Note the brownish discoloration surrounding meristematic root tips (arrows), and the browning response along the lengths of the root, in comparison to the control treated with water. (B) Effects of 
glucan $(\mathrm{G})$, chitosan $(\mathrm{CHSN})$ or chitin $(\mathrm{CH})$ treatment of roots on transcript abundance of the $\mathrm{Sp}$ $A M P$ gene at 1 and 5 days, measured using qRT-PCR, as described above. Data represent $S p$ $A M P$ transcript copy number change compared to the control seedlings. Error bars indicate the standard error across three biological replicates.

Fig. 6. Effects of yeast mutants on $S p-A M P$ transcription. Scots pine roots were inoculated with yeast mutants with either 4-fold reduced levels of chitin ( $\Delta$ chs5 mutant (Santos et al., 1997)) or increased levels of $\beta$-(1,6)-glucan ( $\Delta$ exg mutant (Cappellaro et al. 1998)). Transcript abundance of $S p-A M P$ genes was measured using qRT-PCR at 1 and 5 days. Data represent $S p-A m p$ transcript copy number change compared to that of the control inoculated with wild type $S$. cerevisiae. Error bars indicate the standard error across three biological replicates.

Fig. 7. Sequence comparison and homology modeling. (A) Sequence alignment of Sp-AMP1, Sp-AMP2, MiAMP1 and a number of similar plant proteins is shown, with conserved residues colored red (identical), green (strongly similar) or blue (weakly similar), defined according to the algorithms of CLUSTAL W. A related sequence that represents several fungal proteins is highlighted in yellow at the bottom. Residues that differ among the Sp-AMPs are marked with above the sequences, while those on the proposed binding surface are marked with + below. (B) Ribbon cartoon of the Sp-AMP3 homology model, showing the conserved disulfide bonds in crimson. A manually modeled laminaritetraose in light steel blue is shown for purposes of comparison, not to suggest a particular mode of binding. (C) Molecular surface calculated based on the homology model, colored according to sequence conservation among the plant proteins (ranging from yellow for the non-conserved residues, to red for those completely conserved). 
The most conserved faces of the protein are shown; conserved residues not on the putative binding surface represent buried residues critical to the protein's fold. (D) Stereo representation of the proposed binding surface with modeled laminaritetraose; portions of the protein structure have been removed for clarity. The tryptophan residues (Trp6 and Trp72) that could explain the fluorescence changes are also shown. 
Figure 1. 
(A)

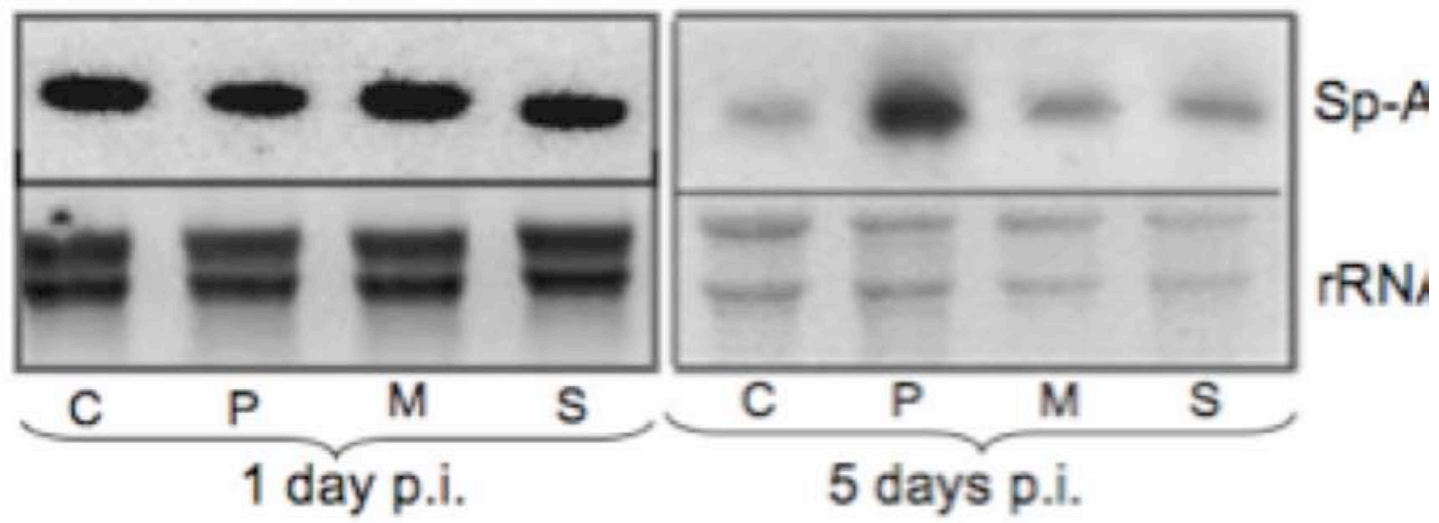

(B)

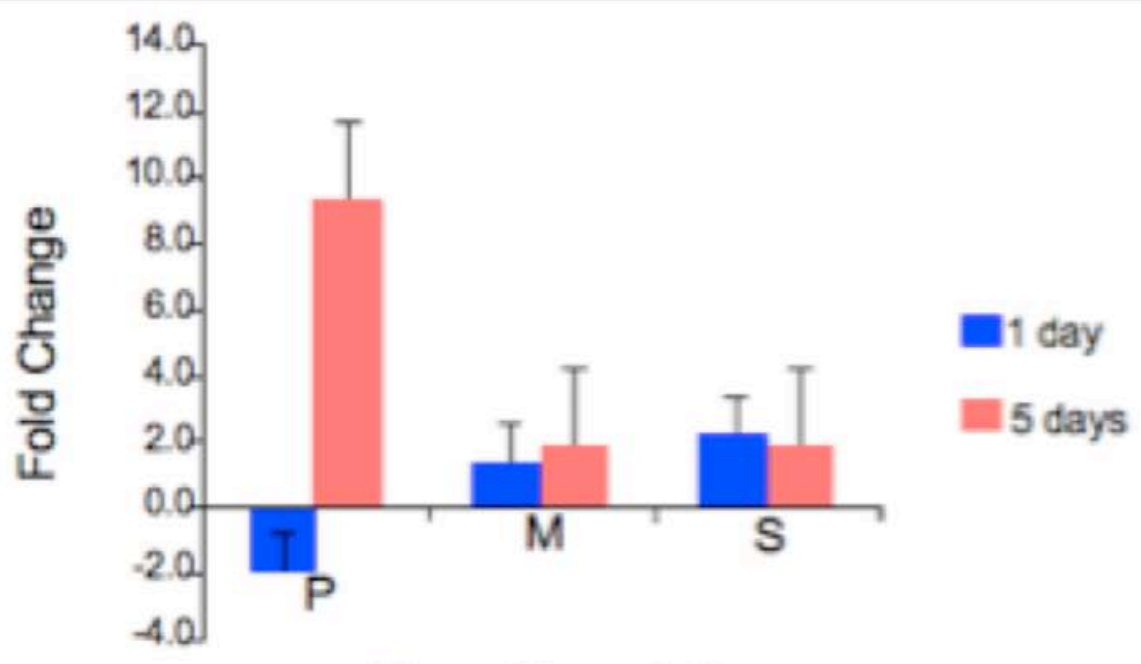

Fungal inoculation

(C)

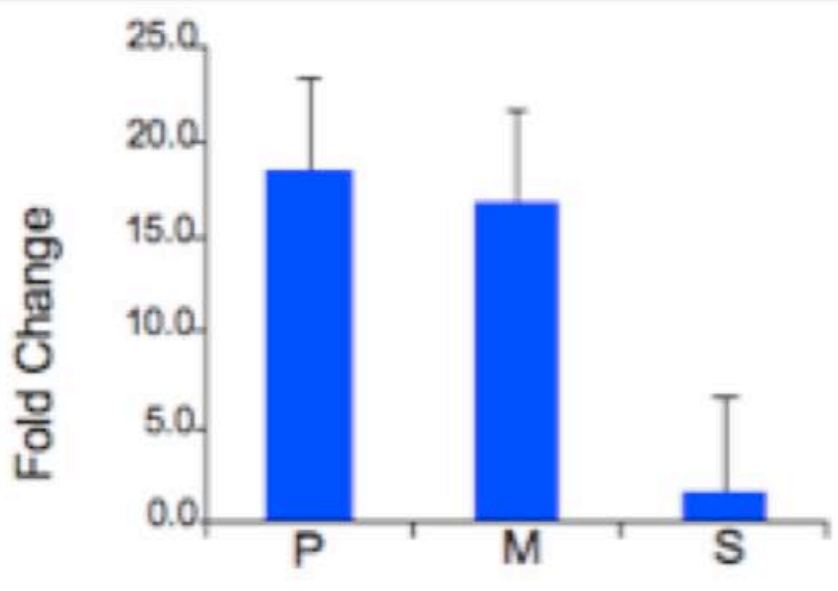

ESP-AMP

Protoplast inoculation 
Figure 2.

(A)

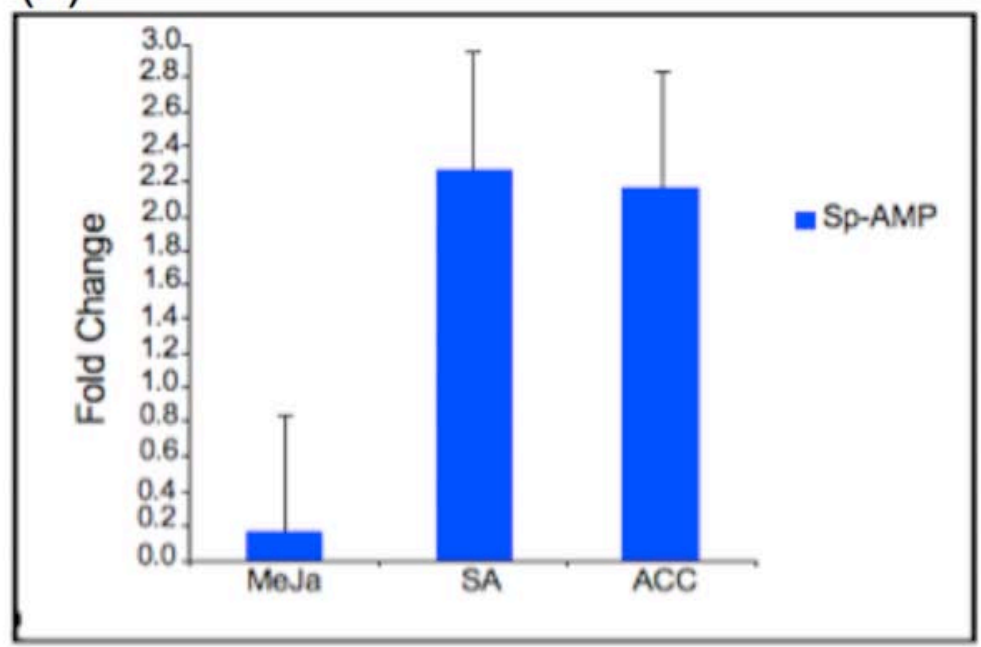

(B)

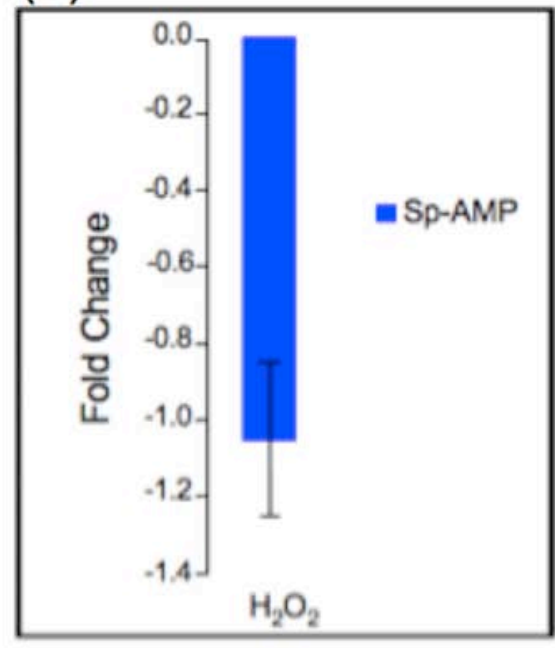


Figure 3.

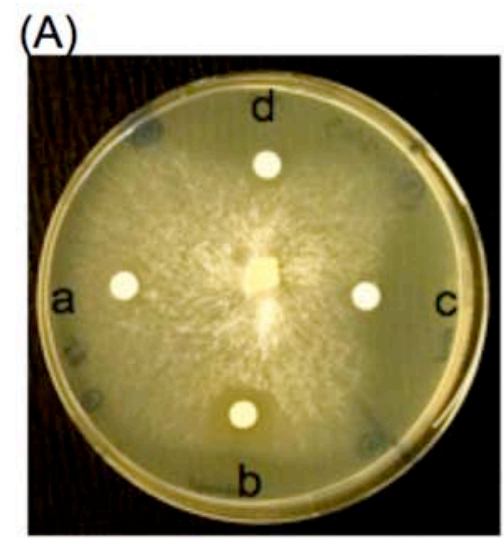

(B)

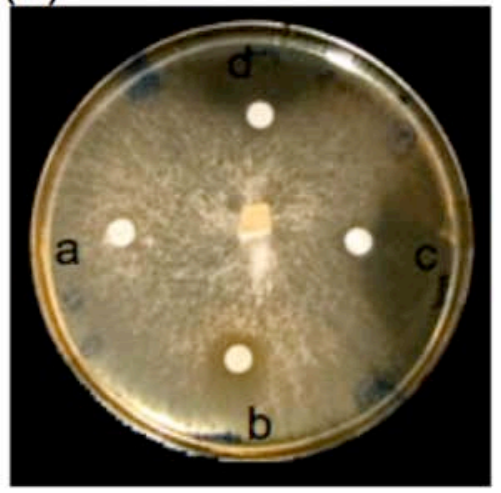

(D)

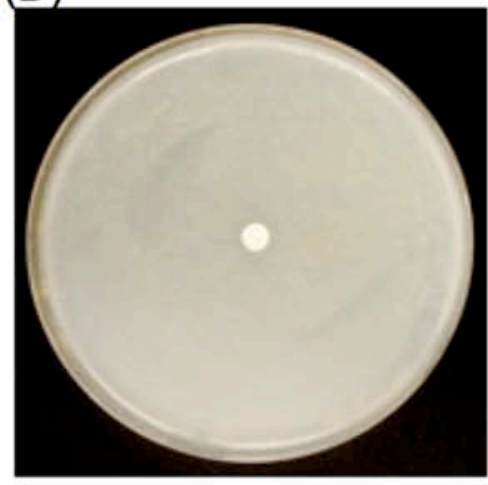

(E)

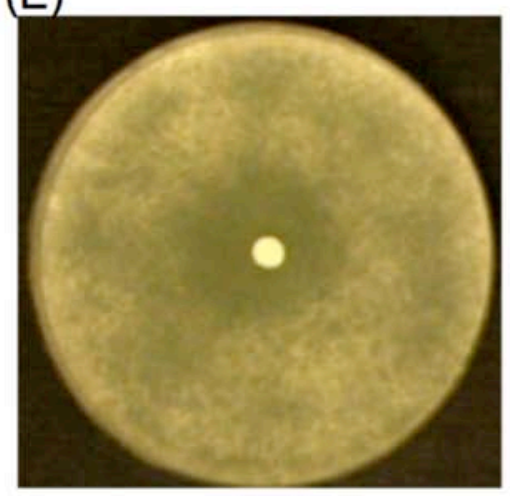

(C)

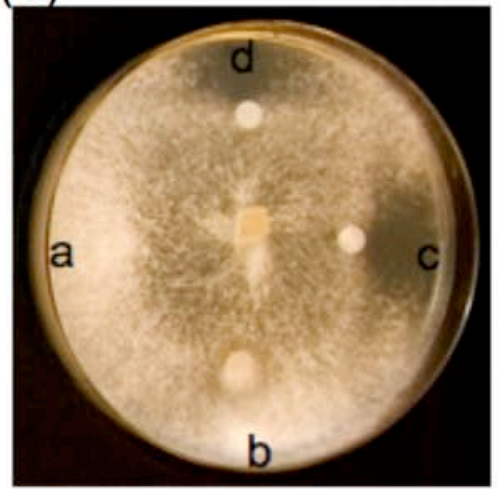


Figure 4.

(A)

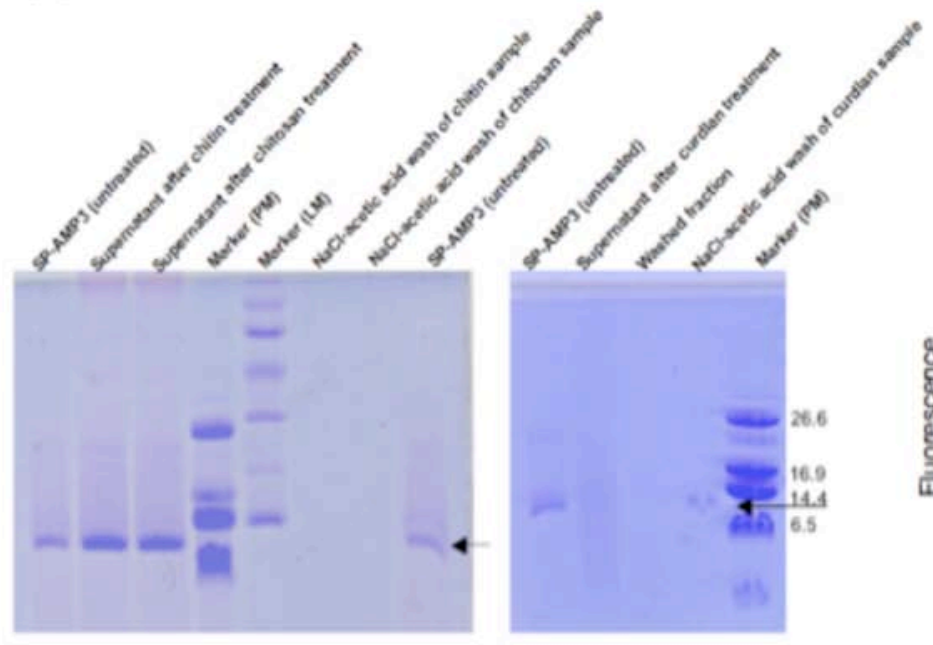

(B)

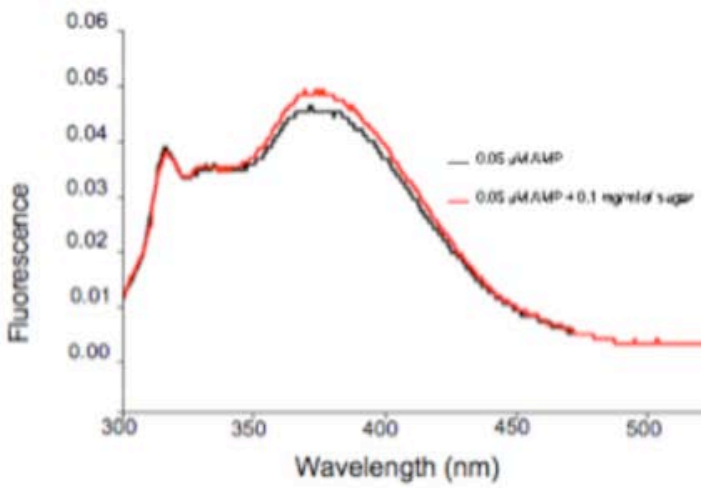


Figure 5.

(A)

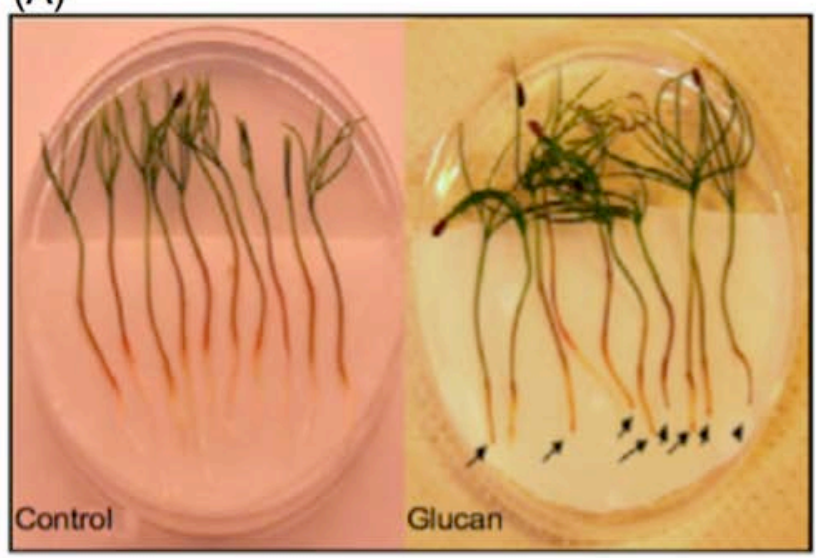

(B)

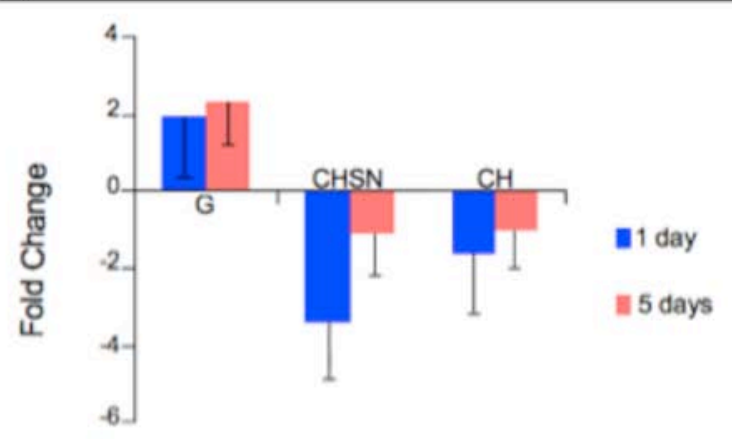

Glucan, chitosan and chitin treatment 
Figure 6.

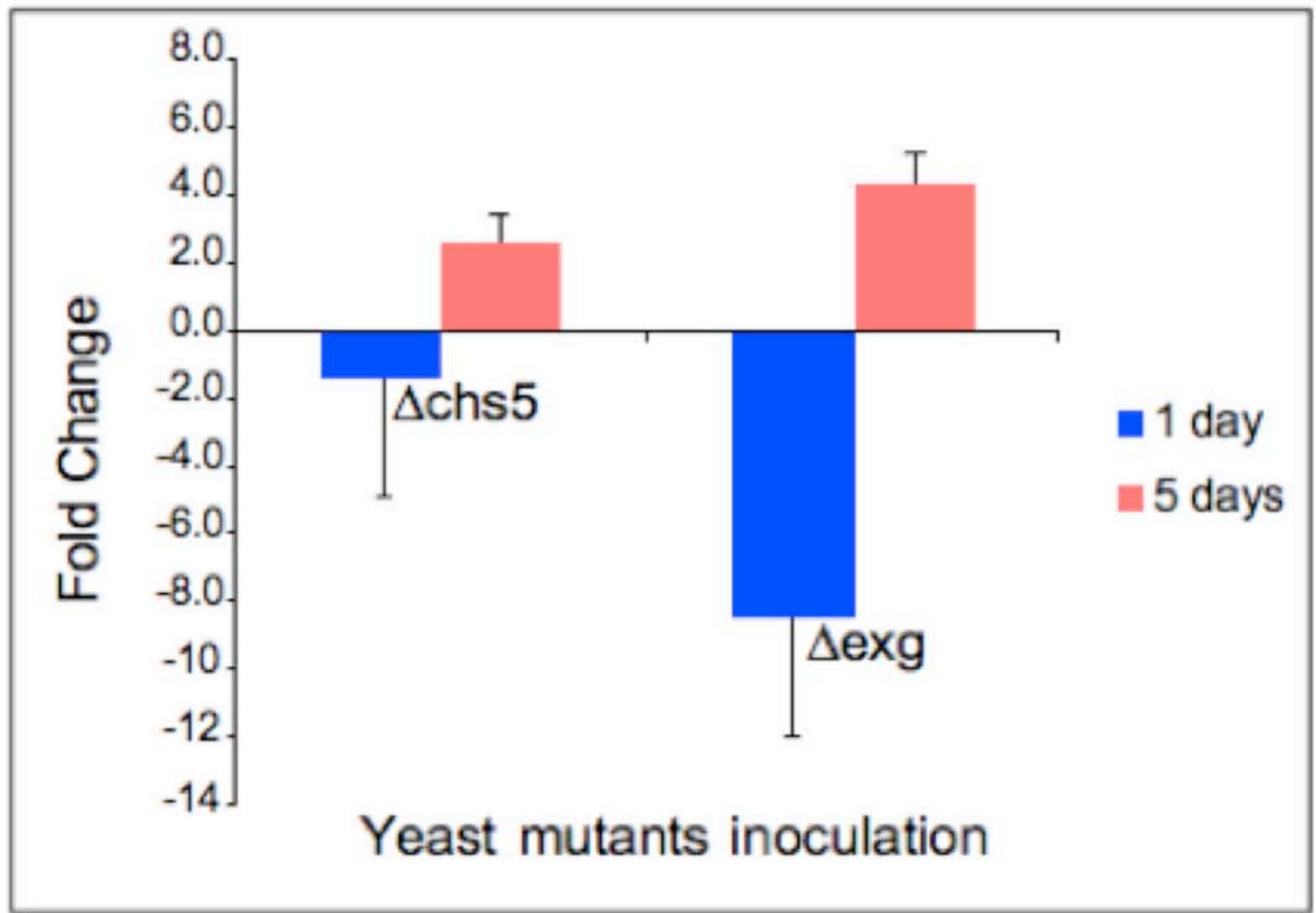


Figure 7.

(A) Sp_AMP1 SP AMP2

Macademia integrifolia Anborella trichopoda Pinus pinaster Pinus plnaster Zantedeschia aethiopica prcea sitenenain Dicea glauca

Selaginella a
Selaginellab

Selaginellab

Papaver somniferum

Sorghum bicolour $-\mathrm{b}$

zea mays

Sorghu bicolour-a

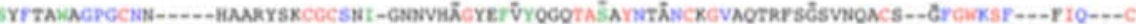

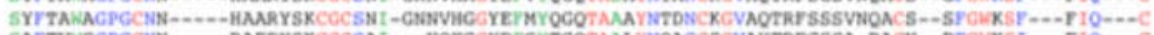

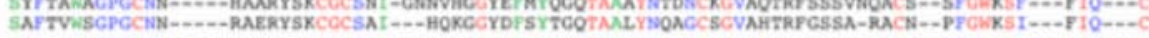

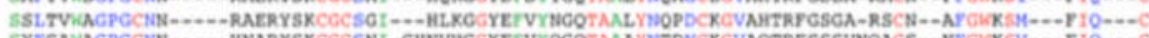

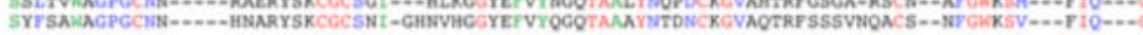

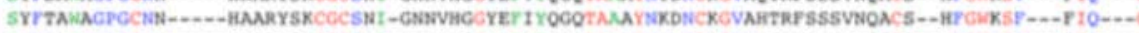

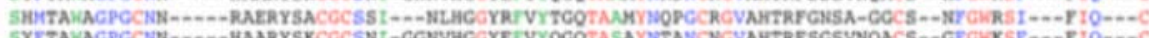
SYrFA

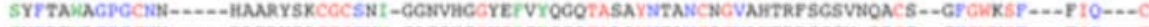

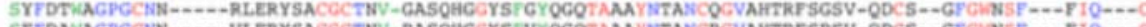

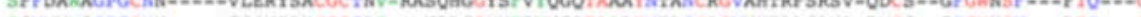

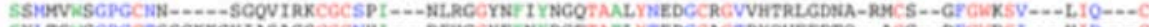

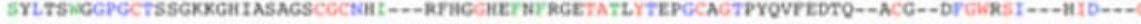

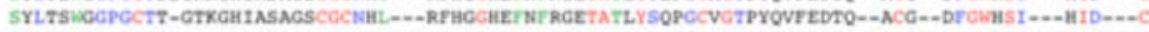

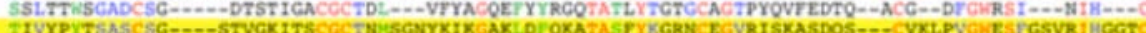
Aspergilius sp.

(B)

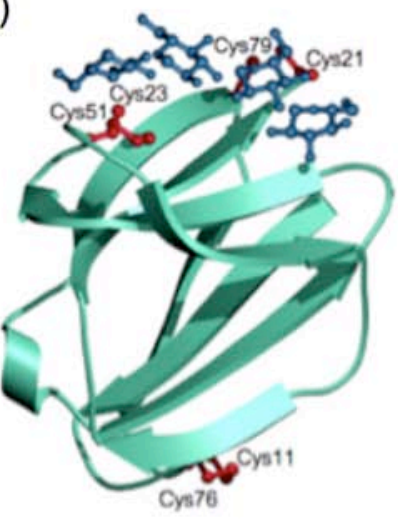

(C)

(D)

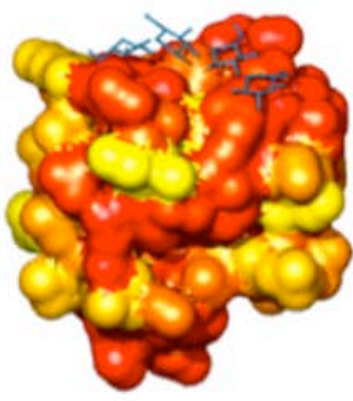

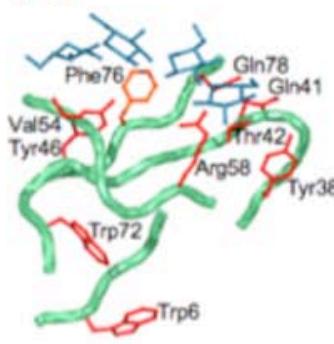

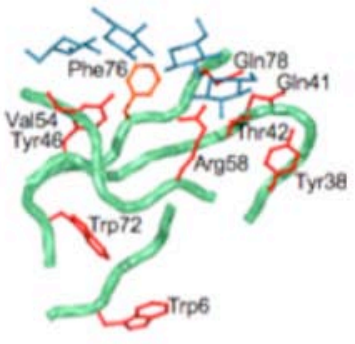

